Israel Law Review 54(2) 2021, pp 143-173. C The Author(s), 2021. Published by Cambridge University Press in association with the Faculty of Law, the Hebrew University of Jerusalem. This is an Open Access article, distributed under the terms of the Creative Commons Attribution licence (http://creativecommons.org/licenses/by/4.0/), which permits unrestricted re-use, distribution, and reproduction in any medium, provided the original work is properly cited.

doi:10.1017/S0021223720000278

\title{
Absolutist Admissibility at the ICC: Revalidating Authentic DOMESTIC INVESTIGATIONS
}

\author{
Michael A Newton*
}

First published online on 16 March 2021

\begin{abstract}
Current jurisprudential trends empower the International Criminal Court (ICC) Prosecutor to override domestic investigative authorities in a manner that violates the letter and spirit of the Rome Statute. Sovereign states have primary responsibility to document, investigate and prevent atrocity crimes. Yet, current ICC practice subverts domestic enforcement efforts. No provision of the Rome Statute permits the Office of the Prosecutor (OTP) to substitute its unfettered judgment over the good-faith discretion of domestic prosecutors. ICC judges have created de facto institutional jurisdictional primacy by relying upon mere assertions regarding the insufficiency of domestic efforts. This trend is particularly problematic at the liminal phase from the preliminary examination (PE) to an authorised investigation because OTP policy preferences supersede good-faith domestic investigations and prosecutorial assessments. Juridical templates for assessing admissibility have been extrapolated from later phases of particularised cases into the PE phase. Current practice effectively eliminates sovereign prosecutorial discretion. Good-faith exercises of domestic prosecutorial discretion should not be constrained by post hoc Court-created straitjackets. This article dissects this problematic arc and proffers a model for harmonising domestic investigative efforts within the structure and intent of the Rome Statute. Its conclusions recommend reforms to ameliorate a foreseeable crisis of cooperation that could cripple an unreformed Court.
\end{abstract}

Keywords: admissibility, proprio motu, prosecutorial discretion, complementarity, preliminary examinations, domestic investigative discretion

Pretexts are at least a homage which unjust men pay to justice. He who screens himself with them shows that he still retains some sense of shame. He does not openly trample on what is most sacred in human society; he tacitly acknowledges that a flagrant injustice merits the indignation of all mankind. Emer de Vattel $^{1}$

\section{INTRODUCTION}

The Prosecutor and the Pre-Trial Chambers of the International Criminal Court (ICC) have created a mechanical template for addressing admissibility determinations in the early phases of

\footnotetext{
* Professor of the Practice of Law and Professor of the Practice of Political Science, Vanderbilt University Law School, United States; mike.newton@vanderbilt.edu; http:/law.vanderbilt.edu/bio/michael-newton. The author is deeply appreciative of the diverse group of friends and experts who shaped these thoughts. Of particular note, the aforementioned group includes Peter Robinson, Dov Jacobs, Kevin Jon Heller, Rogier Bartels, and the participants of the 2020 ICC Scholars Forum. Any errors and oversights are attributable solely to the author and are his responsibility.

${ }^{1}$ Emer de Vattel, The Law of Nations (first published 1758, Béla Kapossy and Richard Whatmore (eds), Liberty Fund 2008) 486-87.
} 
litigation that torques the institutional centre of gravity far from its intended purpose. The structure of the Rome Statute $^{2}$ requires that ICC prosecutorial discretion should dovetail with goodfaith domestic authority in a synergistic but respectful manner. ${ }^{3}$ The jurisdictional relationship between the ICC and sovereign states represents a tiered allocation of authority to adjudicate. The Court's institutional design functions from the ground up as the forum of last resort in order to 'promote values fundamental to all democratic and peace-loving states' ${ }^{4}$ The pursuit of justice is not a zero sum game in which good-faith domestic investigations that do not result in criminal charges represent setbacks to the authority and legitimacy of the Court. The principle of complementarity (as implemented in the admissibility regime via the juridical tests embodied in Article 17 of the Rome Statute) is the fulcrum of this fundamentally important allocation of prosecutorial authority. This fragile treaty-based balance must be implemented at all phases of ICC proceedings.

The Court's jurisprudential arc endangers the healthy synergy that is the cornerstone of the Rome Statute. This article seeks to ameliorate that trend. Section 2 examines the Court's institutional design. Section 3 explores the concept of admissibility against its actual implementation at the preliminary examination (PE) phase of proceedings, while Section 4 addresses potential counter-arguments in favour of the jurisprudential status quo. Section 5 describes the attributes of domestic enforcement efforts that warrant deference, while Section 6 proffers specific recommendations to preserve jurisdictional compatibility between the ICC and sovereign states. Superimposing unexamined prosecutorial preferences of the Office of the Prosecutor (OTP) over the good-faith reasoning of domestic officials applying the law of the sovereign effectively eviscerates the intellectual foundations of the Court.

The credibility of the Court as a permanent institutional enterprise demands that admissibility should receive more than pro forma rationalisation at every stage of proceedings. As it matures, the admissibility jurisprudence has begun to replace the textual model allocating shared authority between domestic and supranational processes with one built on a presumption of competition between the ICC and domestic investigative authorities. As one noted expert has observed, the

\footnotetext{
${ }^{2}$ Rome Statute of the International Criminal Court (entered into force 1 July 2002) 2187 UNTS 90 (Rome Statute), Preamble (exhorting sovereign states to take measures at the national level but cautioning that the treaty-based ICC 'shall be complementary to national criminal jurisdictions'); Report of the Special Rapporteur on the Promotion of Truth, Justice, Reparation and Guarantees of Non-Recurrence and the Special Adviser to the Secretary-General on the Prevention of Genocide, Joint Study on the Contribution of Transitional Justice to the Prevention of Gross Violations and Abuses of Human Rights and Serious Violations of International Humanitarian Law, including Genocide, War Crimes, Ethnic Cleansing and Crimes against Humanity, and Their Recurrence (6 June 2018), UN Doc A/HRC/37/65, paras 10-15.

${ }^{3}$ Lovisa Badaågård and Mark Klamberg, 'The Gatekeeper of the ICC: Prosecutorial Strategies for Selecting Situations and Cases at the International Criminal Court' (2017) 48 Georgetown Journal of International Law 639 (noting that Office of the Prosecutor (OTP) policy and strategy straddles law and politics at multiple levels and describing the evolving relationship with domestic processes); Michael A Newton, 'A Synthesis of Community-based Justice and Complementarity' in Christian D Vos, Sara Kendall and Carsten Stahn (eds), Contested Justice: The Politics and Practice of International Criminal Court Interventions (Cambridge University Press 2015) 122.

${ }^{4}$ Bartram S Brown, 'Primacy or Complementarity: Reconciling the Jurisdiction of National Courts and International Tribunals' (1998) 23 Yale Journal of International Law 383, 436.
} 
ICC 'has been viewed as a legitimate substitute of domestic jurisdiction (i.e. Katanga, Gbabo). In other cases, it has been perceived as a competing forum (Libya), or even as an obstacle to domestic justice efforts (Kenya)'. ${ }^{5}$

These tensions are most pronounced at the onset of an investigation. The gap between aspiration and actuality is expanding at the time of this writing. At the PE phase, admissibility poses no more of an obstacle to OTP discretion than a weather strip across a doorway. The stringent standards imposed on states provide stark contrast with the perfunctory manner in which the OTP leaps over admissibility as a barrier to its own discretion. ${ }^{6}$ However, the admissibility regime represents the load-bearing pillar of institutional legitimacy. Debates over the distribution of OTP prosecutorial prerogatives and the power of the ICC judiciary have been ubiquitous in the work of the Court, ${ }^{7}$ yet the prerogatives of domestic authorities to exercise appropriate discretion during investigation and charging decisions have been devalued.

Domestic duties to conduct effective investigations are not an obligation of result, but of means. ${ }^{8}$ Good-faith domestic investigations (what the Rome Statute terms 'genuinely' in Article 17) should be entitled to deference by the OTP. In the phrasing of one of the most distinguished commentators in the field, sovereign states are entitled to a wide range of responses provided that: ${ }^{9}$

[prosecutorial decision making does not derive from] apathy or a desire to protect perpetrators, which may properly be criticized as inconsistent with the fight against impunity. According to this approach, $a$ State would be judged on its compliance with the duty to prosecute by an analysis of its motives rather than its actions.

Procedural differences between normal domestic criminal investigations and those conducted in the context of and associated with alleged atrocity crimes are to be expected. Careful explication of the contextual goal of an appropriate and good-faith investigation may well allow harmonisation of atrocity law within established international standards. ${ }^{10}$ Such an approach would align

\footnotetext{
${ }^{5}$ Carsten Stahn, 'Admissibility Challenges before the ICC: From Quasi-Primacy to Qualified Deference?' in Carsten Stahn (ed), The Law and Practice of the International Criminal Court (Oxford University Press 2015) 228, 229.

${ }^{6}$ See text to $\mathrm{nn} 22-29$.

${ }^{7}$ ICC, Situation on Registered Vessels of the Union of the Comoros, the Hellenic Republic and the Kingdom of Cambodia, Judgment on the Appeal of the Prosecutor against the Pre-Trial Chamber I 'Decision on the "Application for Judicial Review by the Government of Comoros", ICC-01/13-98 OA2, Appeals Chamber, 2 September 2019, paras 76-77; ICC, Situation in the Islamic Republic of Afghanistan, Judgment on the Appeal against the Decision on the Authorisation of an Investigation into the Situation in the Islamic Republic of Afghanistan, ICC-02/17 OA4, Appeals Chamber, 5 March 2020, paras 61-63 (rejecting Pre-Trial Chamber limitations on the scope of OTP investigatory authority) (Afghanistan, Appeals Chamber Article 53 PTC Ruling). ${ }^{8}$ ECtHR, Jaloud $v$ The Netherlands, App no 47708/08, 20 November 2014, para 166.

${ }^{9}$ William A Schabas, The International Criminal Court: A Commentary on the Rome Statute (2nd edn, Oxford University Press 2016) 457 (emphasis added, internal reference removed).

${ }^{10}$ ECtHR, Hassan v United Kingdom, App no 29750/09, 16 September 2014, para 104. ('accommodating', as far as possible, the power to detain in international armed conflict with the right to liberty, but expressly declining to extend that right broadly into all armed conflict scenarios).
} 
ICC practice with the intentions of the Rome Statute drafters by validating domestic efforts to undertake genuine investigations designed to administer justice and initiate criminal proceedings when warranted and feasible.

The ICC Appeals Chamber has implicitly accepted this tenet because 'sparse and disparate' efforts of domestic investigators considered in light of their 'number and frequency' do not demonstrate genuine domestic investigations. ${ }^{11}$ Qualitative assessment of domestic processes may warrant an inference of unreasonableness or bad faith in certain circumstances. Yet, no provision of the Rome Statute pre-empts domestic prosecutorial prerogatives based solely on misalignment between domestic investigations and the specific charges against specific perpetrators deemed suitable by the supranational court. At the time of this writing the OTP has turned that premise on its head at the PE phase.

Contrary to the letter and spirit of the Rome Statute, unfettered OTP discretion erodes the sovereign prerogatives of all states. Judicial templates for assessing the authenticity of domestic actions in light of the admissibility criteria at the PE stage have migrated in toto from subsequent phases into the earliest phases of ICC proceedings without appropriate modification. The bedrock treaty premise 'in favour of domestic jurisdictions only applies where it has been shown that there are (or have been) investigations and/or prosecutions at the national level'. ${ }^{12}$ Where no relevant investigations and/or prosecutions were ongoing at the national level, the presumption does not apply. ${ }^{13}$ Applying extant jurisprudence, ICC judges infer domestic inaction at later stages of proceedings if a specific perpetrator was not investigated at the domestic level. ${ }^{14}$ One of the most distinguished experts in the field refers to this as the "third - unwritten - condition of the complementarity test'. ${ }^{15}$ This results in automatic findings of admissibility that empower the OTP. Current case law forces ICC judges to rely on unsupported assertions by the Prosecutor that the relevant situation comports with the admissibility criteria when considering requests under Article $15 .{ }^{16}$

The specificity of admissibility analysis from cases at much later phases of investigation and charging is illogical when transplanted to the PE phase. ${ }^{17}$ The most recent OTP Strategic Plan

\footnotetext{
${ }^{11}$ ICC, Prosecutor v Simone Gbagbo, Judgment on the Appeal of Côte d'Ivoire against the Decision of Pre-Trial Chamber I of 11 December 2014 entitled 'Decision on Côte d'Ivoire's Challenge to the Admissibility of the Case against Simone Gbagbo', ICC-02/11-01/12 OA, Appeals Chamber, 27 May 2015, para 131.

12 ibid para 59.

${ }^{13}$ ICC, Prosecutor v Alfred Yekatom and Patrice-Edouard Ngaïssona, Decision on the Yekatom Defence's Admissibility Challenge, ICC-01/14-01/18-593, Trial Chamber V, 28 April 2020, para 18 (Yekatom, Trial Chamber V Decision on Admissibility).

${ }^{14}$ Assuming that the Pre-Trial Chamber is otherwise satisfied with art 12 jurisdiction and the procedural requirements of art 13 in the particular situation.

${ }^{15}$ William A Schabas, 'The Rise and Fall of Complementarity' in Carsten Stahn and Mohammed M El Zeidy (eds), The International Criminal Court and Complementarity: From Theory to Practice (Vol. I, Cambridge University Press 2014) 150, 159.

${ }^{16}$ Afghanistan, Appeals Chamber Article 53 PTC Ruling (n 7) para 40 ('in the view of the Appeals Chamber, it is sufficient for the purposes of the article 15 procedure that the Prosecutor considers the admissibility of potential cases in determining whether she should request authorisation for an investigation under article 15(3) of the Statute; there is no basis for the pre-trial chamber to consider that question as well').

${ }^{17}$ See text to nn $54-69$.
} 
acknowledges that 'at the preliminary examination phase' the 'relatively narrow test' derived from extant jurisprudence for considering conflicts with domestic jurisdictions is applied in 'a similar (though relatively less strict [manner]) ... to the potential cases that the Office identifies'. ${ }^{18}$ Applying this latitude at the PE stage when seeking formal authorisation of investigations from Pre-Trial Chambers, the OTP has consistently disregarded domestic investigations and other enforcement efforts. ${ }^{19}$ In practice, ICC judges permit the OTP to disregard domestic decisions based on generalised assertions that remain unexamined. ${ }^{20}$ Nor do ICC judges require granular analysis of the perceived inadequacies of pre-existing domestic decision making. Reliance on such prosecutorial assumptions creates unwarranted asymmetry between the Court and domestic prosecutors, which contravenes the drafters' intentions.

While it is beyond the scope of this article to rehash the definitive balance of powers between the Court and domestic jurisdictions, ${ }^{21}$ an obliteration of complementarity in practice at any stage of ICC proceedings shatters the Court's institutional assumptions. Fidelity to the Spirit of Rome and the fabric of the Rome Statute requires cooperative synergy between states and the Court based on the shared commitment to the principles of justice and equality of arms in the investigation or prosecution of perpetrators. There is no hint in the negotiating record that an absolutist mandate of the Prosecutor is, or should be, dispositive at any phase of ICC proceedings. Unconstrained and unexplained deference to OTP preferences contravenes the text and the spirit of Article 17. In a similar vein, the OTP concept of domestic investigations that are sufficient to preclude admissibility is unsupported and inexcusably narrow. The following sections describe this disconnect and proffer reasoned solutions.

\section{Admissibility in Theory AND Practice}

The ICC was not created to impose supranational dominance over the prosecutorial practices and priorities of states with developed systems and demonstrated adherence to the rule of law. ${ }^{22}$ The

\footnotetext{
${ }^{18}$ OTP, Strategic Plan 2019-2021, 17 July 2019, 17, https://www.icc-cpi.int/itemsDocuments/20190726-strategicplan-eng.pdf.

${ }^{19}$ See text to nn $75-91$

${ }^{20}$ To its credit, the OTP Strategic Plan (n 18) seems to recognise the current imbalanced state of the law by conceding that future complementarity assessments may increasingly require the Office and the Chambers of the Court also to examine the second limb of the complementarity assessment in relation to whether the state concerned is unwilling or unable genuinely to investigate or prosecute. This would need to take into account how the competent domestic authorities have or are carrying out the proceedings in the context of their own domestic legal framework and practice. As such, it is likely that understanding and practice around complementarity and the assessment of 'genuineness' will evolve over the course of the current strategic plan.

${ }^{21}$ Mohammed El Zeidy, The Principle of Complementarity in International Criminal Law: Origins, Development, and Practice (Brill 2008) 59.

${ }^{22}$ During negotiations of the Elements of Crimes for the Rome Statute, the author repeatedly heard the argument that 'this permanent Court is for the Saddam Husseins of the world'. The ironic truth is that the prosecution of Saddam and other leading Ba'athists took place in an internationalised domestic forum precisely because, inter alia, Iraqis saw grave injustice arising from prosecuting only the subset of crimes committed after 1 July 2002 as required by the jurisdictional limitations of the Rome Statute: Michael A Newton and Michael P Scharf, Enemy of the State: The Trial and Execution of Saddam Hussein (St Martin's Press 2008) 76-80. Moreover, established UN judges and structures refused to aid Iraqi judges: Michael A Newton, 'Iraq's New Court Finds Itself on Trial', New York Times Op-ed, 24 November 2004. See also Schabas (n 9) 446-47.
} 
OTP approach to admissibility determinations at the PE phase reflects its own categorical imperative. ${ }^{23}$ That approach creates consistency amongst various stages of ICC proceedings at the expense of branding domestic investigations as insufficient with no critique, no granular examination of purported defects, and no opportunity for rebuttal.

Mechanisms that uphold the principle of complementarity are integrated into all three departments of the Court (the OTP, the Pre-Trial and Trial Chambers, and the Appeals Chambers) to ensure that the Court exercises only its proper scope of authority with the ever-present possibility of review, albeit entirely internal institutional review. Ignoring the institutional DNA vis-à-vis admissibility represents a radical (and heretofore unacknowledged) redesign of the Rome Statute. Admissibility cannot be cast aside with the wave of the Prosecutor's wand at any phase of Court proceedings.

Insofar as the Rome Statute embodies textual formulations crafted to sustain the authority of all sovereign states, the Court should view considerations of complementarity and legal grounding as matters of utmost prudence and best practice. This is the Statute's homogeneous design. Against this backdrop, Canadian diplomat John Holmes noted: ${ }^{24}$

Throughout the negotiating process, States made clear that the most effective and viable system to bring perpetrators of serious crimes to justice was one which must be based on national procedures complemented by an international court... The success in Rome is due in no small measure to the delicate balance developed for the complementarity regime ... it remains clear to those most active throughout the negotiations that any shift in the balance struck in Rome would likely have unravelled support for the principle of complementarity and, by extension, the Statute itself.

The current misalignment creates at least three structural challenges to the administration of apolitical justice in The Hague. First, the OTP proffers no specific basis for disregarding the validity of domestic investigations at the PE phase. Pre-Trial Chambers accept such proffers of admissibility with little or no judicial comment or analysis..$^{25}$ This is especially problematic at the PE phase because OTP filings are almost entirely reliant upon third-party information derived from United Nations sources, reports of non-governmental organisations, UN experts' reports, or press reporting. Given that the proprio motu power represents the precise point of friction between the power of an independent and supposedly impartial prosecutor and sovereign authorities, the current approach seems destined to create controversies and allegations of excessive politicisation by the Court. In proprio motu cases brought under Article 15, the Prosecutor has no

\footnotetext{
${ }^{23}$ See text to nn $68-90$.

${ }^{24}$ John T Holmes, 'The Principle of Complementarity' in RS Lee (ed), The International Criminal Court: The Making of the Rome Statue - Issues, Negotiations, and Results (Kluwer Law International 1999) 41, 73-74.

${ }^{25}$ ICC, Situation in the Republic of Cote d'Ivoire, Decision pursuant to Article 15 of the Rome Statute on the Authorisation of an Investigation into the Situation in the Republic of Côte d'Ivoire, ICC- 02/11-14, Pre-Trial Chamber III, 3 October 2011, para 206 (Côte d'Ivoire, Admissibility Decision); ICC, Situation in the Republic of Kenya, Decision pursuant to Article 15 of the Rome Statute on the Authorisation of an Investigation into the Situation in the Republic of Kenya, ICC-01/09-19, Pre-Trial Chamber II, 31 March 2010, para 54 (Kenya, Admissibility Decision).
} 
obligation to notify states of her intention to seek authorisation for an investigation. Even if she did so as a matter of comity, there is no textual basis for them to create a trial record opposing prosecutorial discretion. ${ }^{26}$ This disadvantages any party to litigation that seeks to challenge the admissibility determination, because there are at present no clear standards for assessing the sufficiency of previous or ongoing domestic investigations. Nor are there clear judicial findings or articulated legal frameworks against which to appeal.

Second, the perfunctory manner of admissibility determinations at the PE phase marks a significant transfer of authority to the Court. Though particular perpetrators or states may challenge the legal basis of jurisdiction and/or admissibility at later phases of proceedings, the OTP has latitude in the liminal phase from PE to investigations authorised by Pre-Trial Chambers under Article 15(4) in ways that undermine the design of the Statute. At subsequent phases of proceedings, ICC Chambers have routinely required submissions from concerned states prior to making rulings in admissibility challenges. ${ }^{27}$ Current practice at the PE phase forces domestic prosecutors to defer to the Court's subsequent choice of perpetrators and the structure of the OTP cases. Such misguided application creates a doubly difficult Catch 22 because states have no textual licence to satisfy admissibility through newly authorised domestic investigations responding to OTP prosecutorial preferences once the general nature and theory of OTP charging becomes public.

Finally, as a pragmatic matter, the OTP concedes that it suffers from 'overall basic size and capacity constraints'. ${ }^{28}$ Indeed, the very purpose for requiring Pre-Trial Chambers to assess the $\mathrm{PE}$ is to judicially filter 'unwarranted, frivolous or politically motivated investigations' ${ }^{29}$ OTP tendencies to disregard domestic investigations that are not symmetrical to its own prosecutorial preferences - either in the choice of potential perpetrators or in the specificity of charging decisions - exacerbate its resource constraints, while undermining perceptions of its legitimate authority.

\subsection{The Gestalt of AdmissibiLITy}

The Rome Statute combines a complex blend of civil law, common law, customary international law and sui generis concepts, bound by the premise that sovereign states are

\footnotetext{
${ }^{26}$ Afghanistan, Appeals Chamber Article 53 PTC Ruling (n 7) para 40.

${ }^{27}$ ICC, Situation in the Central African Republic II in the case of Prosecutor v Alfred Rombhot Yekatom and Patrice-Edouard Ngaïssona, ICC-01/14-01/18, Yekatom Defence Appeal Brief: Admissibility, Appeals Chamber, 19 May 2020, para 25 ('This is the first case in the history of the International Criminal Court where a Chamber decided an admissibility challenge based on complementarity without hearing from the concerned State. The Defence contends that the Trial Chamber made a procedural error when denying the Defence's admissibility challenge without first seeking observations from CAR authorities').

${ }^{28}$ OTP, 'Policy Paper on Case Selection and Prioritisation', 15 September 2016, para 11, https://www.icc-cpi.int/ itemsDocuments/20160915_OTP-Policy_Case-Selection_Eng.pdf.

${ }^{29}$ Côte d'Ivoire Admissibility Decision (n 25) para 21, n 26 (citing Morten Bergsmo and Jelena Pejic, 'Article 15: Prosecutor' in Otto Triffterer (ed), Commentary on the Rome Statute of the International Criminal Court: Observer's Notes, Article by Article (2nd edn, Beck/Hart 2008) 591.
} 
interdependent components of a larger global civil society accepting principles of justice as a common good. ${ }^{30}$ Early drafts allowed 'inherent' ICC jurisdiction over some crimes. ${ }^{31}$ In fact, the 1994 International Law Commission (ILC) draft included a provision that allowed the ICC to have automatic jurisdiction over the crime of genocide, which would have created a truly concurrent jurisdiction over those offences. ${ }^{32}$ In this vein American delegates supported an inherent jurisdictional scheme for the genocide offences. ${ }^{33}$ The preamble to the Rome Statute restates the duty of all states to investigate atrocity crimes and to prosecute such cases based on available evidence. From the Court's perspective, jurisdiction under the provisions of Article 12 and admissibility under Article 17 are necessary predicates for the exercise of supranational ICC authority. Both treaty provisions resulted from years of intensive diplomatic effort.

The paradox of a world in which the ICC attempts to function without the cooperation of states is that the very claims of authority and prosecutorial power based on principle lead to decreased authority in practice. Debate over the cooperative structures between the Court and domestic states was a 'major problem', which generated much controversy and became the crux of negotiations. ${ }^{34}$ With the notable exception of referrals from the UN Security Council under Article 13(b), ${ }^{35}$ the treaty text embeds a constrained scope of supranational jurisdiction

\footnotetext{
${ }^{30}$ Leila N Sadat and S Richard Carden, 'The New International Criminal Court: An Uneasy Revolution' (2000) 88 Georgetown Law Journal 381, 386. For an excellent summary of the negotiating dynamic in Rome that resulted in the current Statute, see Ruth Wedgwood, 'Fiddling in Rome: America and the International Criminal Court' (1998) 77 Foreign Affairs 20; M Cherif Bassiouni, 'From Versailles to Rwanda in Seventy-Five Years: The Need to Establish a Permanent International Criminal Court' (1997) 10 Harvard Human Rights Journal 11.

${ }^{31}$ Brown (n 4) 417-28 (describing the advantages and disadvantages of such an inherent supranational scheme).

${ }^{32}$ ILC, Report of the International Law Commission on the Work of its Forty-Sixth Session (2 May-22 July 1994), UN Doc A/49/10 (1994), arts 21(1)(a), 25(1).

${ }^{33}$ David J Scheffer, Ambassador-at-Large for War Crimes Issues and Head of the US Delegation for the UN Diplomatic Conference on the Establishment of a Permanent International Criminal Court, US Department of State, Testimony before the Subcommittee on International Operations of the Senate Foreign Relations Committee, Washington, DC, 23 July 1998, S. Hrg. 105-724, 13 (Ambassador Scheffer referred to a regime of 'automatic jurisdiction over the crime of genocide' in describing the inherent regime of the ILC draft). See also Convention on the Prevention and Punishment of the Crime of Genocide (entered into force 12 January 1951) 78 UNTS 277 (Genocide Convention), art VI (providing that 'persons charged with genocide ... shall be tried by a competent tribunal of the State in the territory of which the act was committed, or by such international penal tribunal as may have jurisdiction with respect to those Contracting Parties which shall have accepted its jurisdiction'). In the 1948 debates over the Genocide Convention, the United States actually made a proposal that sounded remarkably close to the modern formulation of complementarity in the ICC context. The proposal would have added an additional paragraph to art VII of the Genocide Convention to read as follows: 'Assumption of jurisdiction by the international tribunal shall be subject to a finding that the State in which the crime was committed has failed to take adequate measures to punish the crime': Report and Draft Convention prepared by the Ad Hoc Committee on Genocide, UN Doc E/794(1948) (reprinted in Historical Survey of the Question of International Criminal Jurisdiction: Memorandum Submitted by the Secretary-General 142, UN Doc A/CN.4/7Rev.1(1949)).

${ }^{34}$ Kai Ambos, Treatise on International Criminal Law: Foundations and General Part, Vol I (Oxford University Press 2013) 24-25 (noting that two of the six diplomatic meetings held to negotiate the text were dominated by debates over 'the subject of complementarity and jurisdictional boundaries between the ICC and national criminal courts').

${ }^{35}$ Rome Statute (n 2) art 13(b).
} 
grounded in the delegation of authority from consenting states to the Court. ${ }^{36}$ As a logical extension of the necessary textual compromises, Article 18 implicitly places control of investigations with sovereign states, unless the Prosecutor can affirmatively demonstrate that such a decision does not serve the interests of justice.

When the Court exercises jurisdiction through a state party referral or by a proprio motu investigation, the states involved have one month in which to respond with their own investigation. ${ }^{37}$ Under the current formulation of Article 18, if a state notifies the Court of its investigation, the domestic investigation is automatically entitled to primacy unless the Prosecutor submits an application to the Pre-Trial Chamber. ${ }^{38}$ The language is unequivocal: 'the Prosecutor shall defer to the State's investigation of those persons unless the Pre-Trial Chamber, on the application of the Prosecutor, decides to authorize the investigation' ${ }^{39}$ The textual burden lies with the OTP at the point of initiation to prove that the state investigation is insufficient. ${ }^{40}$ This structure preserves state primacy by making deference to good-faith domestic investigations the default response of the Court. If the Prosecutor wants to proceed with the case, she must apply to the Court and affirmatively demonstrate that the state's investigation is inadequate or not authentic. The same principle should apply with even greater force at the more amorphous transition from PE to formal investigation.

The paradigmatic language of Article 17(1) limits OTP authority absent countervailing contextual factors. The formulation that a case is inadmissible unless the domestic state is 'unwilling or unable genuinely' to carry out the investigation or prosecution becomes shorthand for admissibility (termed 'complementarity' in colloquial parlance). The Statute preserves the primacy of domestic authority. ${ }^{41}$ More to the point, the text frames limitations on supranational authority in mandatory (if linguistically awkward) terms.

\footnotetext{
${ }^{36}$ Michael A Newton, 'How the ICC Threatens Treaty Norms' (2016) 49 Vanderbilt Journal of Transnational Law 371; Monique Cormier, 'Can the ICC Exercise Jurisdiction over US Nationals for Crimes Committed in the Afghanistan Situation?' (2018) 16 Journal of International Criminal Justice 1043. Cf Carsten Stahn, 'The ICC, Pre-Existing Jurisdictional Regimes, and the Limits of the Nemo Dat Quod Habet Doctrine - A Reply to Michael Newton' (2016) 49 Vanderbilt Journal of Transnational Law 443; Hans Peter Kaul and Claus Kreß, 'Jurisdiction and Cooperation in the Statute of the International Criminal Court: Principles and Compromises' (1999) 2 Yearbook of International Humanitarian Law 143.

${ }^{37}$ Rome Statute (n 2) art 18(2).

38 ibid.

${ }^{39}$ ibid.

${ }^{40}$ ICC, Prosecutor v Saif Al-Islam Gaddafi and Abdullah al-Senussi, Judgment on the Appeal of Mr Abdullah Al-Senussi against the Decision of Pre-Trial Chamber I of 11 October 2013 entitled 'Decision on the Admissibility of the Case against Abdullah Al-Senussi', ICC-01/11-01/11 OA 6, Appeals Chamber, 24 July 2014, para 298 (Gaddafi and al-Senussi, Appeals Chamber Judgment on Admissibility) (Libya was not shown to be unwilling or unable to prosecute the accused for the same conduct as charged before the ICC and therefore the case was inadmissible before the ICC); Jaloud (n 8) para 226 ('The Court is prepared to make reasonable allowances for the relatively difficult conditions under which the Netherlands military and investigators had to work').

${ }^{41}$ ICC, Prosecutor $v$ Katanga and Ngudjulo, Judgment on the Appeal of Mr Germain Katanga against the Oral Decision of Trial Chamber II of 12 June 2009 on the Admissibility of the Case, ICC-01/04-01/07 OA 8, Appeals Chamber, 25 September 2009, para 85 (Katanga, Appeals Judgment on Admissibility).
} 
The subjective nature of this test generated much debate over the best method for constraining the power of a potentially overweening ICC prosecutor. To that end, Articles 17(2) and (3) detail factors for judicial assessment. ${ }^{42}$ The treaty-based factors enumerated for determining if a state is unwilling to prosecute include whether the proceedings were undertaken for the purpose of shielding the person concerned from criminal responsibility, ${ }^{43}$ whether there was an unjustified delay in the proceedings, ${ }^{44}$ or whether the proceedings were not being conducted independently or impartially. ${ }^{45}$ The determination of the inability of domestic courts to adjudicate the case is "whether, due to a total or substantial collapse or unavailability of its national judicial system, the State is unable to obtain the accused or the necessary evidence and testimony or otherwise unable to carry out its proceedings' ${ }^{46}$ The negotiation record makes plain that these details were intended to guarantee some structure to admissibility assessments.

By contrast, the subjective requirement of 'genuinely' in the formulation of Article 17(1) is left for the Court to ascertain. Early in the life of the Court, this textual gap caused one of the most distinguished international scholars to observe that this aspect of Article 17 is 'enigmatic'. ${ }^{47}$ Accepting the reality that some external standard of review was needed to prevent illusory efforts by states, delegates rejected a series of proposed phrases such as 'ineffective', 'diligently', 'apparently well founded', 'good faith', 'sufficient grounds' and 'effectively' on the basis that such formulations remained too subjective. ${ }^{48}$ In the final analysis, the formulation 'genuinely' was accepted by delegations as being the least subjective concept considered, while at the same time eliminating external considerations of domestic efficiency in the investigation or prosecution. $^{49}$

\subsection{The Current Jurisprudential Approach}

The juridical structure for evaluating admissibility has emerged from diverse contexts and cases. Article 17 requires a two-step process by which domestic officials must investigate allegations and make good-faith judgements either to prosecute or impose other punitive measures. Sincerely stated domestic intentions based on the intent to conduct investigations at some future date or to improve domestic capacity in the wake of societal turmoil are insufficient to meet the

\footnotetext{
${ }^{42}$ Rome Statute (n 2) art 17(2), (3).

${ }^{43}$ ibid art 17(2)(a).

${ }^{44}$ ibid art $17(2)(b)$.

${ }^{45}$ ibid art $17(2)(\mathrm{c})$.

46 ibid art 17(3).

${ }^{47}$ William A Schabas, An Introduction to the International Criminal Court (1st edn, Cambridge University Press 2001) 67.

${ }^{48}$ Rod Jensen, 'Complementarity, "Genuinely" and Article 17: Assessing the Boundaries of an Effective ICC' in Jann Kleffner and Gerben Kor (eds), Complementary Views on Complementarity (Asser Press 2006) 147, 155.

${ }^{49}$ Louise Arbour and Morten Bergsmo, 'Complementarity: National Courts vs the ICC' in Antonio Cassese, Paola Gaeta and John RWD Jones (eds), The Rome Statute of the International Criminal Court: A Commentary (Oxford University Press 2002) Pt 19.1.
} 
requirements of Article 17, leaving the Court free to assert jurisdiction in lieu of deference to domestic actions..$^{50}$

The Court has repeatedly imposed a judicially created requirement that the domestic case must 'sufficiently mirror' the case as developed in the ICC. ${ }^{51}$ Thus, judges will first assess the evidentiary basis for finding that the state challenging admissibility has proved that the national investigation or prosecution focused on the 'same person' and 'substantially the same conduct' as framed in the ICC prosecution..$^{52}$ If these tests are satisfied the Court must then follow the textual requirements of Article 17 and determine whether the supranational jurisdiction predominates because the domestic capacity is either 'unwilling' or 'unable' to 'genuinely' investigate or prosecute the perpetrator.

The Appeals Chamber has clarified that although the burden of proof in an admissibility challenge is not explicit in the Statute, 'a State that challenges the admissibility of a case bears the burden of proof to show that the case is inadmissible'. ${ }^{53}$ Moreover, the Statute requires that states challenge the admissibility of particular cases 'at the earliest opportunity' ${ }^{54}$ The Gaddafi and al-Senussi holdings effectively amended Article 17 by shifting the burden of proof onto the challenging state, despite the language that a case is inadmissible unless the decisions of the domestic state are non-compliant with the statutory tests.

Because domestic states cannot make submissions at the earlier phase of proceedings, transposing that test into the context of an OTP request for authorisation to open a formal investigation under Article 15 deprives domestic officials of their sovereign discretion in the appropriate disposition of atrocity crimes. This reversal obscures the fact that the complementarity structure was an integral component of the overarching compromise that is the bedrock of the ICC. It endangers the healthy interface between the Court and domestic authorities in situation states. Moreover, it demarcates a dangerous point of pressure between the institutional interests of the Court and the inherent prerogatives of states. By extension, corrosion of the complementarity rights of states (both states party and non-states party) undermines the political and economic foundations for a viable permanent Court.

\footnotetext{
${ }^{50}$ ICC, Prosecutor v Muthaura, Kenyatta and Ali, Judgment on the Appeal of the Republic of Kenya against the Decision of Pre-Trial Chamber II of 30 May 2011 entitled 'Decision on the Application by the Government of Kenya Challenging the Admissibility of the Case pursuant to Article 19(2)(b) of the Statute', ICC-01/09-02/ 11-274, Appeals Chamber, 30 August 2011, para 40 (Muthaura and Others, Appeals Chamber Judgment on Admissibility); Yekatom, Trial Chamber V Decision on Admissibility (n 13) para 21 ('the Chamber concludes that the CAR authorities, including the SCC, are presently inactive insofar as Mr Yekatom's Case is concerned. For this reason alone, and irrespective of the CAR authorities' hypothetical willingness or ability to investigate and prosecute, the Chamber is of the view that the case against Mr Yekatom is admissible. Consequently, the Chamber will not address the question of willingness and ability').

${ }^{51}$ ICC, Prosecutor $v$ Saif al-Islam Gaddafi and Abdullah al-Sensussi, Judgment on the Appeal of Libya against the Decision of Pre-Trial Chamber I of 31 May 2013 entitled 'Decision on the Admissibility of the Case against Saif Islam Al-Gaddafi', ICC-01/11-01/11 OA 4, Appeals Chamber, 21 May 2014, para 73; Gaddafi and al-Senussi, Appeals Chamber Judgment on Admissibility (n 40) para 119.

52 ibid paras 82-87.

${ }^{53}$ Gbagbo (n 11) para 29.

${ }^{54}$ Rome Statute (n 2) art 19(5).
} 


\subsection{What is a 'Case’ at the Preliminary Examination Phase?}

The jurisprudence of the Court at the PE phase obligates domestic prosecutors to coordinate investigations and/or make charging decisions based only on the faint hope that the ICC will defer to domestic enforcement efforts. There are no judicially created templates for constraining OTP discretion or guiding domestic decision making. Subordinating domestic charging prerogatives to the prosecutorial discretion of the ICC Prosecutor turns the principle of complementarity on its head.

Unlike the ICC, the principle of ne bis in idem would not preclude a subsequent trial before ad hoc tribunals of an earlier era if 'the characterization of the act by the national court did not correspond to its characterization' in the international forum. ${ }^{55}$ The ad hoc tribunals established under Chapter VII enjoyed inherent jurisdictional superiority vis-à-vis domestic jurisdictions. ${ }^{56}$ Dicta of the International Criminal Tribunal for the former Yugoslavia (ICTY) accordingly supported the notion that an international criminal tribunal 'must be endowed with primacy over national courts' because human nature will create a 'perennial danger of international crimes being characterized as "ordinary crimes". ${ }^{57}$

Rule 11bis in the ad hoc tribunals created identical standards for the transfer of pending cases to domestic courts by requiring that the state have jurisdiction in one of three ways: (i) the crime was committed in the state; (ii) the accused was arrested in the state; or (iii) the state has jurisdiction and is willing and adequately prepared to accept the referral. ${ }^{58}$ Rule 11 bis also required the state to possess a legal framework that criminalises the alleged conduct of the accused and provides an adequate penalty structure. Judges of the International Criminal Tribunal for Rwanda (ICTR) clarified that the criminalisation requirement must be for a crime of the same nature as the charges envisioned in the supranational forum: ${ }^{59}$

'[i]n assessing whether a State is competent within the meaning of Rule 11 bis to accept one of the Tribunal's cases, a designated Trial Chamber must consider whether it has a legal framework which criminalizes the alleged conduct of the accused and provides an adequate penalty structure'.

\footnotetext{
${ }^{55}$ Report of the Secretary-General pursuant to Paragraph 2 of Security Council Resolution 808 (1993) (3 May 1993), UN Doc S/25704, adopted by UN Security Council (UNSC) Res 827, Tribunal (Former Yugoslavia) (25 May 1993), UN Doc S/RES/827, para 66 (describing the overlap of domestic prosecutorial authority with the concurrent jurisdiction and presumption of primacy under the International Criminal Tribunal for the former Yugoslavia (ICTY)).

56 ibid. See also UNSC Res 827 (ibid); UNSC Res 955 (8 November 1994), UN Doc S/Res/955.

${ }^{57}$ See ICTY, Prosecutor v Tadic, IT-94-AR72, Decision on the Defence Motion for Interlocutory Appeal on Jurisdiction, 2 October 1995, para 58 (this path-breaking opinion discussed charging distinctions justifying the primacy of ICTY jurisdiction).

${ }^{58}$ ICTY, Prosecutor v Pasko Ljubičič, Decision to Refer the Case to Bosnia-Herzegovina pursuant to Rule 11bis, IT-00-41PT, 12 April 2006 (providing background to the adoption and evolution of Rule 11bis in the ICTY); ICTY, Prosecutor v Željko Mejakić, Momčilo Gruban, Dušan Fuštar and Duško Knežević, Decision on Prosecutor's Motion for Referral of Case pursuant to Rule 11bis, IT-02-65-PT, 20 July 2005.

${ }^{59}$ ICTR, Prosecutor v Bagaragaza, Decision on Prosecutor's Request for Referral of the Indictment to the Kingdom of the Netherlands, Judgment, ICTR-2005-86-11bis, Trial Chamber III, 13 April 2007, para 11 (reference removed).
} 
The Tribunal only has authority to refer cases where the State 'will charge and convict [or acquit] only for those international crimes listed in its Statute' as opposed to 'ordinary crimes' such as homicide.

The Chamber did note that it considered the term 'case' to be a broad term: ${ }^{60}$

The Appeals Chamber agrees with the Prosecution that the concept of a 'case' is broader than any given charge in an indictment and that the authorities in the referral State need not necessarily proceed under their laws against each act or crime mentioned in the Indictment in the same manner that the Prosecution would before this Tribunal.

Although the presumption of supranational supremacy is unwarranted in the ICC admissibility regime, case law has developed in its shadow. Pre-Trial Chambers have uniformly analysed jurisdiction along with preliminary assessments of admissibility prior to issuing a warrant for the arrest of perpetrators. ${ }^{61}$ The Lubanga opinion granting the warrant of arrest states: ${ }^{62}$

The first part of the test relates to national investigations, prosecutions and trials concerning the case at hand insofar as such case would be admissible only if those States with jurisdiction over it have remained inactive in relation to that case or are unwilling or unable, within the meaning of article 17 (1) (a) to (c), 2 and 3 of the Statute. The second part of the test refers to the gravity threshold which any case must meet to be admissible before the Court.

The decision in Lubanga clarified the scope of supranational authority vis-à-vis domestic processes. Setting the template for future analysis of a 'case' under Article 17, the Chamber noted: ${ }^{63}$

[I]t is a conditio sine qua non for a case arising from the investigation of a situation to be inadmissible that national proceedings encompass both the person and the conduct which is the subject of the case before the Court.

This legacy is important because the noun 'case' is used in Article 17(1)(a) and (b).

Extant jurisprudence articulating the 'same person' and 'substantially the same conduct' standards arises from much later phases of litigation. In the sense that the bench is evaluating specific charges against a named perpetrator in relation to the issuing of a warrant of arrest or confirmation of charges, ${ }^{64}$ the term 'case' is suitable. By sharp contrast, Article 15(6) is the only reference to the undefined concept of the PE found in the Rome Statute.

\footnotetext{
${ }^{60}$ ICTR, Prosecutor v Bagaragaza, Decision on Rule 11bis Appeal, ICTR-05-86-AR11bis, Appeals Chamber, 30 August 2006, para 17.

${ }^{61}$ ICC, Situation in Uganda, Warrant of Arrest for Joseph Kony issued on 8 July 2005 as amended on 27 September 2005, ICC-02/04-01/05-53, Pre-Trial Chamber II, 27 September 2005, para 38, https://www.icccpi.int/pages/record.aspx?uri=97185.

${ }^{62}$ ICC, Prosecutor $v$ Thomas Lubanga Dyilo, Decision on the Prosecutor's Application for a Warrant of Arrest, Article 58, ICC-01/04-01/06-1, Pre-Trial Chamber I, 10 February 2006, para 29, https://www.legal-tools.org/doc/ af6679/pdf.

${ }^{63}$ ibid para 31.

${ }^{64}$ Rome Statute (n 2) arts 58, 60(5), 61.
} 
However, at the PE there is no such thing as a 'case' to be considered. The triggering procedures specified in Article 15 apply not to 'cases' but to situations 'generally defined in terms of temporal, territorial, and in some cases personal parameters'. ${ }^{65}$ The term 'case' in Article 17(1) focuses on particularised perpetrators and potential charges rather than the broader situation. The systematic integrity and operation of domestic enforcement efforts should be the core of the jurisprudential inquiry during consideration of a PE rather than the Prosecutor's present evaluation of specific charges against particular persons. Thus, admissibility assessment at the PE phase must have a much broader and more functional interpretation to ensure logical consistency with the intent of the Statute.

Admissibility determinations at the PE phase should mirror the preliminary nature of the proceedings. Complementarity is nothing if not a pragmatic and limiting principle. A broader situational evaluation at the liminal phase should align admissibility practice with the complementary design of the Court. Hence, 'the contours of the likely cases will often be relatively vague because the investigations of the Prosecutor are at their initial stages' ${ }^{66}$ Of natural consequence, judges must apply the meaning of the word 'case' in a functional manner that is 'understood in the context to which it is applied'. ${ }^{67}$

As a logical consequence, because a broad range of domestic charges could conceivably satisfy admissibility assessments at later phases of litigation, good-faith domestic investigative efforts should be entitled to a broad presumption of deference at the PE phase. The Appeals Chamber specifically abandoned the practice of the ad hoc tribunals by recognising that the Rome Statute does not require perfect duplication of the substantive crimes charged. ${ }^{68}$ Domestic prosecutors have liberty to frame a wide range of analogous domestic offences (so called 'ordinary' crimes) in lieu of substantive descriptions drawn solely from international norms. Intellectual symmetry mandates that while domestic officials cannot be artificially constrained by the substantive descriptions of crimes found in the Rome Statute, ${ }^{69}$ nor should domestic investigations be forced into a narrow template moulded around conformity with OTP expectations.

\footnotetext{
${ }^{65}$ ICC, Situation in the Democratic Republic of the Congo, Decision of the Applications for Participation in the Proceedings of VPRS 1, VPRS 2, VPRS 3, VPRS 4, VPRS 5 and VPRS 6, ICC-01/04-101-tEN-Corr, Pre-Trial Chamber I, 17 January 2006, para 65. See also Rod Rastan, 'Situation and Case: Defining the Parameters' in Stahn and El Zeidy (n 15) 421.

${ }^{66}$ Muthaura and Others, Appeals Chamber Judgment on Admissibility (n 50) para 39.

${ }^{67}$ ibid; Kenya, Admissibility Decision (n 25) 48.

${ }^{68}$ Roger O’Keefe, International Criminal Law (Oxford University Press 2015) 560 (citing Gaddafi and al-Senussi, Appeals Chamber Judgment on Admissibility (n 40) paras 214-31); William A Schabas, An Introduction to the International Criminal Court (5th edn, Cambridge University Press 2017) 174 (noting that domestic prosecutors have a degree of discretion that 'clearly does not require that the national prosecutions be identical to those of the International Criminal Court').

${ }^{69}$ Michael A Newton, 'The DoD Law of War Manual as Applied to Coalition Command and Control' in Michael A Newton (ed), The United States Department of Defense Law of War Manual: Commentary and Critique (Cambridge University Press 2019) 360, 374-79 (noting ICC jurisprudence and state practice rejecting the concept of mirror charging as being inconsistent with the drafters' intentions and the text of the Statute).
} 


\section{CReating the Illusion of InACtion}

The Court's decisions at the time of this writing force sovereign states to play a dangerous guessing game with regard to the validity of ex ante domestic investigations or prosecutions. They simultaneously face the conundrum that Article 17 requires investigations or charging decisions prior to any OTP efforts. An ICC that routinely overrides good-faith investigative actions and subsequent decision-making discretion of domestic officials will inevitably confront a crisis of cooperation. This is the Achilles heel of admissibility, and it is one fashioned by the Court. Moreover, the jurisdictional structure of Article 12 imposes this dilemma on all sovereign states whether or not they are part of the Rome Statute system.

Pre-Trial Chamber I created this gap in Lubanga: ${ }^{70}$

The first part of the test relates to national investigations, prosecutions and trials concerning the case at hand insofar as such case would be admissible only if those States with jurisdiction over it have remained inactive in relation to that case or are unwilling or unable, within the meaning of Article $17(1)$ (a) to (c), (2) and (3) of the Statute.

The Chamber dropped a footnote to this text noting that this interpretation is 'a contrario of Article $17^{\prime} \cdot{ }^{71}$ The judges concluded that 'in the absence of any acting State, the Chamber need not make any analysis of unwillingness or inability'. ${ }^{72}$ This finding might have been limited to specific analysis given the context of state referral to the ICC (also a factor in Yekatom). In other instances Chambers have omitted discussion of domestic actions taken with regard to the crimes alleged before deciding to advance a particular case. ${ }^{73}$ This trend culminated in the Appeals Chamber affirmation of the case against Germain Katanga: ${ }^{74}$

Therefore, in considering whether a case is inadmissible under article 17 (1) (a) and (b) of the Statute, the initial questions to ask are (1) whether there are ongoing investigations or prosecutions, or (2) whether there have been investigations in the past, and the State having jurisdiction has decided not to prosecute the person concerned. It is only when the answers to these questions are in the affirmative that one has to look to the second halves of sub-paragraphs (a) and (b) and to examine the question of unwillingness and inability. To do otherwise would be to put the cart before the horse. It follows that in case of inaction, the question of unwillingness or inability does not arise; inaction on the part of a State having jurisdiction (that is, the fact that a State is not investigating or prosecuting, or has not done so) renders a case admissible before the Court, subject to article 17 (1) (d) of the Statute.

At subsequent stages of ICC proceedings, the Appeals Chamber has made plain that domestic investigations or prosecutions addressing 'substantially the same conduct' as envisioned in the

\footnotetext{
${ }^{70}$ See $\mathrm{n} 62$.

${ }^{71}$ ibid n 19.

72 ibid para 40.

${ }^{73}$ Kenya, Admissibility Decision (n 25) paras 50-62.

${ }^{74}$ Katanga, Appeals Judgment on Admissibility (n 41) para 78 (emphasis added).
} 
ICC investigation preclude ICC authority because the sovereign state has taken 'concrete and progressive' steps towards authentic accountability. ${ }^{75}$ Extrapolating that prong of the Article 17 test into the PE phase makes findings of inadmissibility legally impossible because no one in the OTP or in Chambers knows which perpetrators will be charged for which patterns of conduct. ${ }^{76}$ This juridical test is nonsensical at the PE phase because domestic enforcement efforts cannot be evaluated against hypothetical charges in some indeterminate future 'case'. Sovereign states must therefore try to predict the future pathway of OTP decision making.

The OTP has sidestepped this difficulty by the artifice of simply asserting inaction by relevant domestic officials. This jurisprudential tactic benefits the OTP because it functions as a trapdoor through which considerations of comity vanish. Artificially created inferences of inaction empower the ICC regardless of the time, cost or investigative efforts undertaken in the real world by sovereign states. This represents a form of judicial jiu jitsu by which the OTP whitewashes the framework of admissibility from the fabric of the Rome Statute through its own assertion and framing of hypothetical cases. This recurrent practice empowers plenary OTP authority at the outset of investigations.

These disparate strands of jurisprudence should be inapposite at the PE phase because the OTP need only assert the inadequacy of domestic efforts. In the Kenya cases, for example, Pre-Trial Chamber II accepted the OTP proffer that the domestic investigations and prosecutions concerning the post-election period were directed against offences and 'persons that fall outside the category of those who bear the greatest responsibility and are likely to be the focus of the Prosecutor's investigation' ${ }^{77}$ By presuming inactivity in the situation, despite widespread investigative and prosecutorial action, the bench avoided any analysis of the factors required under Article 17 to find admissibility. Nor did the Bench require the OTP to bear any burden or produce any evidence to demonstrate specific inadequacies. It merely framed an anticipated scope of investigation that voided the actions actually taken by the Kenyan government and Attorney General.

Likewise, in her November 2017 filing requesting the Pre-Trial Chamber to authorise a formal investigation into the Afghanistan situation, the Prosecutor observed that it is only national criminal investigations and/or prosecutions of a State that can trigger the application of article 17(1)(a)-(c)'. ${ }^{78}$ The Prosecutor acknowledged the 'complementary relationship between the ICC and national criminal jurisdictions'. ${ }^{79}$ She nevertheless dismissed the years of American

\footnotetext{
${ }^{75}$ Gaddafi and al-Senussi, Appeals Chamber Judgment on Admissibility (n 40) para 87.

${ }^{76}$ ICC, Situation in the People's Republic of Bangladesh/Republic of the Union of Myanmar, Decision pursuant to Article 15 of the Rome Statute on the Authorisation of an Investigation into the Situation in the People's Republic of Bangladesh/Republic of the Union of Myanmar, ICC-01/19-27, Pre-Trial Chamber III, 14 November 2019, para 115 (taking note of the OTP submission and observing that given 'the open-ended nature of the Request - there are at present no specific suspects or charges - and the general nature of the available information, the Chamber sees no need to conduct a detailed analysis, as this would be largely speculative').

${ }^{77}$ Kenya, Admissibility Decision (n 25) para 185.

${ }^{78}$ ICC, Situation in the Islamic Republic of Afghanistan, Public Redacted Version of 'Request for Authorisation of an Investigation pursuant to Article 15', 20 November 2017, ICC-02/17-7-Conf-Exp, ICC-02/17-7-Red, Pre-Trial Chamber III, 20 November 2017, para 268 (Afghanistan, OTP Request).

79 ibid.
} 
investigations, along with the millions of dollars expended and the public record running to tens of thousands of pages. The OTP filing accomplished this with a cursory wave by noting (inaccurately) that ' $[\mathrm{t}] \mathrm{he}$ Prosecution observes that a number of the national inquiries described below do not appear to have had full investigatory powers or conducted full criminal inquiries' ${ }^{8} 0$

In reality, the public record of American action is voluminous. The OTP portrait of investigative/prosecutorial sloth would be quite a shock to Americans incarcerated for offences related to the OTP filing, or those who lost careers in the aftermath of official investigations, or those who spent years conducting painstaking analysis into allegations of detainee abuse. For example, the Second Periodic Report on the US implementation of the Convention Against Torture notified the Committee of the array of completed or ongoing investigations related to allegations of detainee mistreatment. As of May 2006, the United States: ${ }^{81}$

[had conducted] more than 600 criminal investigations into allegations of mistreatment, and more than 250 individuals have been held accountable for detainee abuse. Their punishments have included courts-martial, prison terms for as long as ten years, formal reprimands and separation from our military services.

The Annex to the US Report noted that in respect of incidents from Afghanistan, 22 out of 23 criminal investigations had been substantiated, with another seven ongoing by mid-2005. ${ }^{82}$

The United States conducted 12 formal investigations, lasting many years, which involved complex coordination and costly inter-agency analysis. While public records run to tens of thousands of pages, supplemented by an unknown number of pages containing classified materials, judges permitted the OTP to ignore domestic processes by virtue of its own framing of potential charges and perpetrators. ${ }^{83}$ Despite the fact that more than 200 Americans were prosecuted or disciplined in domestic proceedings ${ }^{84}$ OTP filings discount domestic enforcement on the premise that domestic officials did not pursue the precise charges against the precise individuals deemed appropriate by supranational prosecutorial discretion. This result-oriented approach turns Article 17 on its head and impermissibly appropriates plenary prosecutorial discretion to the OTP.

To conform with the intentions of the drafters of the Rome Statute, the OTP should bear the burden of making its prima facie admissibility case at all phases of proceedings. Pre-Trial Chamber II declined to require any evidence to support the bland OTP assertion; nor did it

\footnotetext{
${ }^{80}$ ibid.

${ }^{81}$ Barry F Lowenkron, Opening Statement for US Hearing at Committee Against Torture (CAT), 5 May 2006, https://2009-2017.state.gov/j/drl/rls/68558.htm.

${ }^{82}$ UN Committee against Torture, Consideration of Reports Submitted by States Parties under Article 19 of the Convention: Second Periodic Reports of States Parties due in 1999 - United States of America (29 June 2005), UN Doc CAT/C/48/Add.3, Annex I, 66-69; See also Human Rights Watch, 'By the Numbers: Findings of the Detainee Abuse and Accountability Project', 5 April 2006, 25-29 (noting that 54 of 64 persons charged in courts martial were convicted of at least one charge).

${ }^{83}$ Afghanistan, OTP Request (n 78).

${ }^{84}$ US Department of State, 'One-Year Follow-up Response of the United States of America to Priority Recommendations of the Human Rights Committee on its Fourth Periodic Report on Implementation of the International Covenant on Civil and Political Rights', 31 March 2015, para 8.
} 
sua sponte request more facts related to the OTP position on admissibility ${ }^{85}$ Furthermore, neither the OTP nor the Pre-Trial Chamber evaluated good-faith instances of prosecutorial discretion which followed extensive American investigations. Given the textual presumptions embedded in Article 17 that favour domestic discretion, this approach eliminates complementarity as a constraining principle. It devalues good-faith domestic investigative or prosecutorial decisions.

To be clear, full analysis of the potential admissibility arguments related to American military and CIA action in relation to the Afghanistan situation is far beyond the scope of this article. However, the OTP assertion that the 'information available indicates that at this stage no national investigations or prosecutions have been conducted or are ongoing ${ }^{86}$ against those whom the Prosecutor names in her confidential annex represents a remarkably obtuse display of prosecutorial audacity. OTP submissions at the PE phase created the jurisprudential conditions precedent for the bench to ignore sovereign state prerogatives. OTP speculation mooted any judicial assessments of admissibility because of the OTP framing of potential perpetrators and hypothetical charges. The Pre-Trial Chamber ignored this circularity. The problem from the Court's vantage point is that the US system did not pursue specific charges against the individuals deemed appropriate in the exercise of OTP prosecutorial discretion. In the view of the OTP, failure to provide a specific criminal investigation directed at a specific individual and specific criminal conduct following its preferred mode of liability equates to inaction warranting ICC investigation and potential prosecution. This arrogates discretion to the ICC at the expense of good-faith efforts by domestic authorities. The net result represents jurisprudential bootstrapping because the Court does not have a 'completely free hand' when interpreting its jurisdictional scope as it is not empowered to 'acquire a law-making capacity through its compétence de la compétence' ${ }^{87}$

Moreover, OTP filings deviate from established ICC precedents with no explanation. In the Kenya case the Appeals Chamber listed some examples of appropriate steps used during genuine domestic investigations: 'interviewing witnesses or suspects, collecting documentary evidence, or carrying out forensic analyses' ${ }^{88}$ In Katanga, which came before the Court by virtue of a state referral from the Democratic Republic of the Congo, the bench could point to no witness interviews, suspect interviews, seizures of evidence, or 'noting of facts' ${ }^{9}{ }^{89}$ There was accordingly

\footnotetext{
${ }^{85}$ ICC, Situation in the Islamic Republic of Afghanistan, Decision pursuant to Article 15 of the Rome Statute on the Authorisation of an Investigation into the Situation in the Islamic Republic of Afghanistan, ICC 02/17-33, Pre-Trial Chamber II, 12 April 2019, paras 78-79 (Afghanistan, Admissibility Decision) ('conclusively' finding that admissibility criteria were satisfied based solely upon submissions indicating that domestic 'investigations and prosecutions appear to have focussed (sic) exclusively on direct perpetrators and their immediate superiors' and accepting without discussion or examination the OTP conclusion that 'the reporting and investigation of detainee abuse has been both insufficient and inadequate').

${ }^{86}$ Afghanistan, OTP Request (n 78) paras 299, 312.

${ }^{87}$ Michael Vagias, The Territorial Jurisdiction of the International Criminal Court (Cambridge University Press 2014) 88.

${ }^{88}$ ICC, Situation in the Republic of Kenya, Judgment on the Appeal of the Republic of Kenya against the Decision of Pre-Trial Chamber II of 30 May 2011 entitled 'Decision on the Application by the Government of Kenya Challenging the Admissibility of the Case pursuant to Article 19(2)(b) of the Statute', ICC-01/09-02/11-274, Appeals Chamber, 30 August 2011, para 40, http://www.legal-tools.org/doc/c21f06.

${ }^{89}$ ICC, Situation in the Democratic Republic of the Congo, Prosecution's Response to Document in Support of Appeal of the Defence for Germain Katanga against the Decision of the Trial Chamber 'Motifs de la décision
} 
'nothing procedurally significant that has been established and that could support the allegations that were made,' a point the OTP used to justify admissibility in that case. ${ }^{90}$ In other cases, ICC judges have stressed that the indicia for evaluating domestic discretion derives from actual actions taken by domestic officials such as, inter alia, interviewing witnesses or suspects, collecting documentary evidence, or carrying out forensic examinations. ${ }^{91}$

It defies logic to conclude that the multiplicity of the American Congressional committee, the Inspector General and agency reports related to the Afghanistan situation fail to constitute 'concrete and progressive steps' or were not 'procedurally significant' investigative efforts. Dedicated staffs compiled hundreds of interviews, thousands of pages of supporting documentation, and specific legal and policy analysis regarding the conduct and personnel in question. Moreover, state-run agencies coordinated multiple American investigative efforts that often operated in parallel bureaucratic channels. Involved officials had access to the most highly classified internal correspondence, conducted rigorous review of available facts, and enjoyed subpoena powers to develop new information. Though the OTP discredits some efforts as being purely administrative in nature, American investigations were reviewed by other officials responsible for either initiating separate conventional criminal investigations or criminal prosecutions where warranted (in some instances by the Attorney General personally).

Disregarding such extensive investigative and prosecutorial efforts strengthens the perception of ICC institutional hubris. At a minimum, ignoring domestic efforts to investigate the pattern of conduct alleged by the OTP represents a reordering of the Court's commitment to complementarity. ICC insiders might justify invaliding extensive American investigations on the basis that the conduct in question was egregious. This argument overlooks the fact that all offences proscribed by the Rome Statute are 'the most serious concern to the international community as a whole'. ${ }^{92}$ There is no hint in the text that any of the substantive crimes covered by the Statute warrant supranational primacy under a treaty designed to 'favour national jurisdictions' ${ }^{93}$

Creating the illusion of inactivity permitted the Prosecutor to pretend that the United States was supine in accepting allegations of impropriety against military forces and CIA personnel. This prosecutorial magic trick is all the more remarkable because OTP submissions rely heavily on unclassified information gleaned from the reports of various American agencies, inspectors

oral relative à l'exception d'irrecevabilité de l'affaire', ICC-01/04-01/07-1349, Appeals Chamber, 31 July 2009, para 28.

90 ibid.

${ }^{91}$ ICC, Situation in the Republic of Kenya in the Case of the Prosecutor $v$ William Samoei Ruto, Henry Kiprono Kosgey and Joshua Arap Sang, Judgment on the Appeal of the Republic of Kenya against the Decision of Pre-Trial Chamber II of 30 May 2011 entitled 'Decision on the Application of the Government of Kenya Challenging the Admissibility of the Case', ICC-01/09-01/11 OA, Appeals Chamber, 30 August 2011, paras 41-45 ("Although article 17 (1) (a) to (c) of the Statute does indeed favour national jurisdictions, it does so only to the extent that there actually are, or have been, investigations and/or prosecutions at the national level. If the suspect or conduct have not been investigated by the national jurisdiction, there is no legal basis for the Court to find the case inadmissible') (Appeals Chamber Judgment on the Appeal of the Republic of Kenya Challenging Admissibility).

${ }_{92}$ Rome Statute (n 2) Preamble, art 5.

${ }_{93}^{93}$ Appeals Chamber Judgment on the Appeal of the Republic of Kenya Challenging Admissibility (n 91) para 44. 
general and military bodies. By pretending that US officials took no action to address allegations of offences against detainees in the context of and associated with the armed conflict in Afghanistan, the OTP dodged any incantation of admissibility.

The gravamen of analysis when moving from PE to an authorised investigation should be on the good-faith sufficiency of domestic decision making. To comport with the intent of the Statute, this should be a systematic and holistic analysis because the key concept from Article 17 is 'genuinely'. Permitting the OTP to establish the basis for its own investigatory authority in this manner is circular at best and potentially corrosive to the ICC system. Before considering the attributes that judges could consider as a template for evaluating domestic actions in Section 5, the following section will dissect the legal strands that created the current dilemma at the PE phase.

\section{Potential Arguments for the Status Quo}

A system built on the straightforward assertion of treaty-based supranational primacy was not a 'politically viable alternative for a permanent ICC' ${ }^{94}$ The first President of the Court (who was a Canadian diplomat active during the Rome Statute negotiations) acknowledged that the ICC "will really have to invent, create, and define the meaning of a state that is unable or unwilling to conduct "genuine" proceedings'. ${ }^{95}$ There is palpable tension between exploitation of textual constraints designed to prioritise domestic jurisdiction and natural evolution of treaty provisions crafted to achieve the Court's normative goals. Rather than explicit jurisdictional primacy, the Rome Statute scheme requires progressive factual inquiries that implement an appropriate balance of authority between the supranational court and domestic states. Persistent critiques predicted that complementarity would become an illusory safeguard that would be a constraining tenet on paper with no binding effect in practical application. ${ }^{96}$ In the early years of the Court its opponents anticipated that 'complementarity' would become a pro forma hurdle to justify political and personal manipulations by the Court. ${ }^{97}$

Current developments at the PE phase may well resuscitate arguments of an earlier era. While the Rome Statute ostensibly protects the primacy of domestic jurisdictions, the ICC Prosecutor enjoys unreviewable deference at the PE phase. ${ }^{98}$ Article 15 imposes a minimalist barrier to OTP discretion by requiring only 'a reasonable basis to proceed with an

\footnotetext{
${ }^{94}$ Brown (n 4) 431.

${ }^{95}$ Philippe Kirsch, John Tait Memorial Lecture in Law and Policy, 7 October 2003, cited in Gregory S McNeal, 'ICC Inability Determinations in Light of the Dujail Case' (2007) 39 Case Western Reserve Journal of International Law 325, 325.

${ }^{96}$ See William J Haynes II, 'Explanation of U.S. Position on the ICC', San Francisco World Affairs Council, 30 May 2002 (arguing that 'besides trampling on the authority of sovereign states, the treaty creates a regime that facilitates the abdication of state responsibility').

${ }^{97}$ Diane Sabom, 'ICC Fails Tests of American Justice: Critics Say There Is No System in Place for Holding the International Criminal Court Accountable and Warn that It Could Pose a Significant Threat to U.S. Sovereignty', Insight on the News, 27 May 2002, 18, https://www.questia.com/magazine/1G1-87024941/icc-fails-tests-of-american-justice-critics-say-there.

${ }^{98}$ Afghanistan, Appeals Chamber Article 53 PTC Ruling (n 7) para 37.
} 
investigation'. ${ }^{99}$ This permits superficial reference to domestic authority, generally accompanied by dismissive discourse. This section addresses the jurisprudential basis for devaluing complementarity analysis under Article 15.

\subsection{Relationship between Article 15 and Article 53}

Knowledgeable aficionados may well take the premise of this article as a settled question. Article 15 contrasts with Article 53 by framing OTP obligations but omitting reference to admissibility determinations as a factor subject to judicial review. In reviewing the latitude of the Pre-Trial Chambers to consider OTP assertions of the interests of justice determination pursuant to Article 53, the unanimous Appeals Chamber wrote that 'there is no basis for the pre-trial chamber to consider' the OTP assessment of admissibility under Article $15 .{ }^{100}$ This textualist understanding is narrowly framed but constitutes dicta going well beyond the issues raised in the actual issues certified for appeal. ${ }^{101}$ It is illogical that victims can make representations under Article 15, yet there is no clear OTP obligation to articulate its admissibility analysis for review by Pre-Trial Chambers and responses by potentially affected states. ${ }^{102}$ Strictly limiting the rights of states to raise admissibility during PE hearings subverts their interests by subordinating them to victims.

The textual accuracy of the aforementioned dicta undermines the larger teleological function of admissibility. Considerations of complementarity should not be relegated to the shadows at any phase of ICC proceedings; nor should they be based on supposition or unstated speculation. The OTP is obligated to make affirmative findings to support its filings on the issues of admissibility and jurisdiction. ${ }^{103}$ In contrast, the Statute does not require an affirmative justification of the interests of justice analysis or mandate OTP disclosure of its rationale. ${ }^{104}$ Even if the Appeals Chamber appropriately overturned the uniform practice of Pre-Trial Chambers prior to March 2020, the notion that OTP findings related to admissibility under Article 53 are not reviewable under Article 15 should not alleviate the OTP obligation to make good-faith assessments of domestic enforcement efforts. Phrased another way, the OTP undermines the role of the ICC as the forum of last resort by arbitrarily dismissing domestic investigations and/or prosecutions at the PE phase.

\footnotetext{
${ }^{99}$ Rome Statute (n 2) art 15(3).

${ }^{100}$ Afghanistan, Appeals Chamber Article 53 PTC Ruling (n 7) para 40; Cf Kevin Jon Heller, 'Can the PTC Review the Interests of Justice?', Opinio Juris, 12 April 2019, http://opiniojuris.org/2019/04/12/can-the-ptcreview-the-interests-of-justice (to find that a reasonable basis exists, in short, the OTP must consider (i) jurisdiction, (ii) admissibility, and - critically - (iii) interests of justice).

${ }^{101}$ Dov Jacobs, 'Some Extra Thoughts on Why the ICC Pre-Trial Chamber Acted Ultra Vires in Using the "Interests Of Justice" To Not Open an Investigation in Afghanistan', Spreading the Jam, 12 April 2019, https://dovjacobs.com/2019/04/12/some-extra-thoughts-on-why-the-icc-pre-trial-chamber-acted-ultra-vires-in-usingthe-interests-of-justice-to-not-open-an-investigation-in-afghanistan.

${ }^{102}$ Rome Statute (n 2) art 15(3).

${ }^{103}$ ibid art 53(1).

${ }^{104}$ Kenya, Admissibility Decision (n 25) para 63.
} 


\subsection{InTERfaCe with ARTicle 18}

The ICC should work with states to enhance their domestic capacity and defer to domestic investigations or prosecutions when feasible. However, in the transition from PE to Article 18, the evidentiary burden shifts from the OTP to states. Rather than striving to discount or discredit domestic mechanisms, Chambers and the OTP should provide clear explications of defects in the domestic processes at the earliest possible opportunity. While review of admissibility by the Pre-Trial Chambers under Article 15 might well be of 'limited' value, ${ }^{105}$ Article 18 permits states to 'present detailed information with respect to any question of admissibility' that would permit the PTC to make 'an informed and meaningful assessment'. ${ }^{106}$

Article 18 allows only one month for notifications to the Court of domestic enforcement efforts after receiving notice of an investigation from the OTP. ${ }^{107}$ This short window between authorisation of an investigation and the period for review under Article 18 should incentivise transparency between the OTP and states that would normally exercise criminal jurisdiction at the earliest possible juncture. Failure to require granular analysis and disclosure by the OTP to states at the PE phase forces domestic officials to shadow box based on incomplete information.

Greater OTP transparency would permit situation states 'to receive useful information' that would enhance 'mutual understanding between the Court and the relevant State(s) as to the scope of the complementarity assessment dictated by article 18(2)-(5) of the Statute'. ${ }^{108}$ Obligating the OTP to disclose the basis for its own admissibility determination rather than permitting broad rejection of domestic efforts would facilitate litigation under Article 18. Logically, states should be entitled to appear before the Pre-Trial Chamber and challenge unsupported OTP assertions of domestic inadequacy as the predicate for authorising formal investigations. This also facilitates institutional efficiency.

\subsection{Alleged High-Level Perpetrators}

Long-standing OTP strategy focuses on 'high-level perpetrators' who occupy influential organisational positions. ${ }^{109}$ However, that preference cannot of itself justify distorting the proper balance of prosecutorial discretion between the ICC and domestic officials. OTP submissions that assume away admissibility by disregarding domestic investigations focused on direct perpetrators and their immediate superiors are a recurring theme of ICC litigation. ${ }^{110}$ The notion that

\footnotetext{
${ }^{105}$ Afghanistan, Appeals Chamber Article 53 PTC Ruling (n 7) para 40.

106 ibid para 42.

${ }^{107}$ Rome Statute (n 2) art 18(2).

${ }^{108}$ Kenya, Admissibility Decision (n 25) para 51.

${ }^{109}$ OTP, 'Strategic Plan 2009-2012', Feb 2010, 6. This general policy preference has been tempered by juridical reality to accept that focusing on the most responsible perpetrators will often require a 'building upwards strategy': OTP, 'Strategic Plan 2019-2021', 17 July 2019, para 5(d).

${ }^{110}$ Kenya, Admissibility Decision (n 25) para 185.
} 
investigations should not be assessed solely by reference to their results fully accords with a long line of human rights jurisprudence. ${ }^{111}$

Nevertheless, Pre-Trial Chambers have routinely accepted OTP assertions without requiring further analysis and have 'conclusively' held that OTP submissions that seek to target high-level perpetrators satisfy admissibility criteria. ${ }^{12}$ The Appeals Chamber has implicitly undercut current OTP practice because Article 17 does not require the imposition of 'rigid standards primarily based on top seniority' because 'the preventive role of the Court may depend on many factors, much broader than the capacity of an individual to prevent crimes'. ${ }^{113}$ Notwithstanding its preference for prosecuting high-level perpetrators, the OTP should bear the burden of providing granular information to warrant the inference that domestic enforcement efforts make anticipated cases inadmissible.

Good-faith decisions by experienced prosecutors in accordance with bona fide legal principles bear little resemblance to the picture of indolence in the OTP filing. The essence of admissibility is that ICC judges should not simply provide the rubber stamp to authorise OTP interference in properly functioning domestic systems. Though investigations are the exclusive province of the OTP, judges should require clear articulation of the evidentiary basis for its conclusions related to admissibility. Despite the Article 15(4) mandate that the PTC 'shall authorize the commencement of an investigation', the transition from PE to formally authorised investigation by the OTP is a momentous development for all sovereign states.

With particular relevance to the inference of inaction made by the OTP in the Afghanistan situation, its submission denigrates the involvement of American prosecutors in evaluating the lengthy and comprehensive investigations. The gist seems to be that we, the OTP, can presume a void because US officials did not pursue those persons and criminal charges against those specific officials we seek to pursue. Neither the OTP nor the Pre-Trial Chamber mentioned the US law that provides that: ${ }^{114}$

\footnotetext{
${ }^{111}$ Philip Leach, Clara Sandoval and Rachel Murray, 'The Duty to Investigate Right to Life Violations across Three Regional Systems: Harmonisation or Fragmentation of International Human Rights Law?' in Carla M Buckley, Alice Donald and Philip Leach (eds), Towards Convergence in International Human Rights Law: Approaches of Regional and International Systems (Brill 2016) 32; ECtHR, Al-Skeini v United Kingdom, App no 55721/07, 7 July 2011, para 166 ('As stated above, the investigation must be effective in the sense that it is capable of leading to a determination of whether the force used was or was not justified in the circumstances and to the identification and punishment of those responsible. This is not an obligation of result, but of means. The authorities must take the reasonable steps available to them to secure the evidence concerning the incident, including inter alia eye-witness testimony, forensic evidence and, where appropriate, an autopsy which provides a complete and accurate record of injury and an objective analysis of clinical findings, including the cause of death. Any deficiency in the investigation which undermines its ability to establish the cause of death or the person or persons responsible will risk falling foul of this standard').

${ }_{112}$ Afghanistan, Admissibility Decision (n 85) paras 78-79.

${ }^{113}$ ICC, Situation in the Democratic Republic of the Congo, Judgment on the Prosecutor's Appeal against the Decision of Pre-Trial Chamber I entitled 'Decision on the Prosecutor's Application for Warrants of Arrest, Article 58,' ICC-01/04-169, Appeals Chamber, 13 July 2006, paras 73-74.

${ }^{114}$ Detainee Treatment Act, Pub. L. 109-148, div. A, title X, s 1004, 42 U.S. Code s 2000dd-1(a): Protection of United States Government Personnel Engaged in Authorized Interrogations (2005).
} 
it shall be a defense that such officer, employee, member of the Armed Forces, or other agent did not know that the practices were unlawful and a person of ordinary sense and understanding would not know the practices were unlawful. Good faith reliance on advice of counsel should be an important factor, among others, to consider in assessing whether a person of ordinary sense and understanding would have known the practices to be unlawful. Nothing in this section shall be construed to ... provide immunity from prosecution for any criminal offense by the proper authorities.

This provision mirrors the Rome Statute itself. ${ }^{115}$ President Obama was well within the bounds of propriety by assuring 'those who carried out their duties relying in good faith upon legal advice from the Department of Justice that they will not be subject to prosecution'. ${ }^{116}$ The Director of Central Intelligence admonished his lawyer to make 'sure this is legal' prior to promulgating policies related to detainee treatment. ${ }^{117}$ The Attorney General personally reviewed the full text of classified reporting, and ordered a criminal inquiry led by an experienced prosecutor charged with assessing the evidentiary foundations for the prosecution of senior officials in connection with detainee interrogations. ${ }^{118}$

The US Universal Periodic Review ${ }^{119}$ noted that extensive reviews examined a 'broad universe of allegations from multiple sources' but the prosecutors 'concluded that the admissible evidence would not have been sufficient to obtain and sustain convictions beyond a reasonable doubt'. The OTP presented no contrary evidence to satisfy its burden of proof that domestic actions were attributable to political motives or an ineffective legal system; nor did Pre-Trial Chamber II require such evidence before acceding to that portion of the OTP request with no further analysis. Admissibility requires that good-faith efforts of domestic prosecutors are entitled to deference. The imperatives of the Statute should not be arbitrarily short-circuited at any phase of ICC proceedings.

\section{Indicia of Inadmissible Domestic Investigations at the PE Phase}

This section considers the attributes of effective investigations derived from modern best practices in domestic systems which should be entitled to deference in The Hague. The concept of complementarity is restrictive rather than empowering in seeking to preserve the delicate balance of authority between all states and the supranational Court. The object and purpose of the Rome Statute is emphatically not to create homogeneous standards for atrocity investigations across

\footnotetext{
115 Rome Statute (n 2) art 33(1).

${ }^{116}$ The White House, Office of the Press Secretary, 'Statement of President Barack Obama on Release of OLC Memos', 16 April 2009, https://obamawhitehouse.archives.gov/the-press-office/statement-president-barackobama-release-olc-memos.

${ }^{117}$ Philip Mudd, Black Site: The CIA in the Post-9/11 World (WW Norton and Company 2019) 102.

${ }^{118}$ US Department of Justice, 'Attorney General Eric Holder Regarding a Preliminary Review into the Interrogation of Certain Detainees', 24 August 2009, https://www.justice.gov/opa/speech/attorney-general-ericholder-regarding-preliminary-review-interrogation-certain-detainees.

${ }^{119}$ UN Human Rights Council, National Report submitted in accordance with Paragraph 5 of the Annex to Human Rights Council Resolution 16/21: United States of America (4-15 May 2015), UN Doc A/HRC/WG.6/22/USA/1, para 95.
} 
continents and contexts. To be sure, the Court is not a human rights body created to impose uniformity on sovereign investigative or prosecutorial procedures. ${ }^{120}$ Likewise, inadmissibility should never become dependent upon conformity between the form and procedures of a domestic investigation and those envisioned by the OTP during the PE. Admissibility at its core is a treatybased creation operating as a sui generis concept within the Court.

In the language of Article 17 an effective investigation conducted with indicia of good faith is, by definition, genuine. The ability to require the production of evidence represents the hallmark of genuine investigative effort. Processes for securing key evidence, and the availability of that evidence, for analysis within a parallel criminal investigation or relevant domestic prosecutions remain necessary cornerstones. The Rome Statute obligates domestic investigatory action in accordance with human rights law and jus in bello. Such overlapping duties represent what scholars term 'an opposing norm' in the sense that there is no conflict as both legal regimes include the duty to investigate, but depending on the context would 'prescribe actions that cannot be fulfilled at the same time'. ${ }^{121}$

The Court should respect indicia of due process and systematic thoroughness and require the OTP to analyse specifically those traits of domestic efforts. By assuming inaction based on its own charging preferences, the OTP approach discounts thorough domestic investigations that resulted in prosecutorial declinations based on evidentiary insufficiency or due process concerns. In doing so, the OTP comes close to assuming a presumption of guilt on potential perpetrators without undertaking any effort to document specific defects in domestic processes.

Moreover, post hoc considerations of investigatory efforts should evaluate the context and overall content. ${ }^{122}$ OTP actions in the Kenya, Côte d'Ivoire and Afghanistan situations turn this tenet on its head. Investigative independence paired with fully informed and neutral prosecutorial determinations represent the hallmarks of appropriate domestic efforts which satisfy the duty to investigate under both human rights law and the laws of armed conflict. That information provides necessary background for considering complementarity as a barrier to ICC action. The goal is to ensure that any investigation includes appropriate follow-up and authoritative oversight by informed prosecutorial officials. As a logical corollary, authorities empowered to convene full criminal investigations must separately review any investigation that lacks specific prosecutorial power. Across the situations and radically different contexts mentioned above, neither the OTP nor the Pre-Trial Chambers assessed the granular evidence of relevant relationships between criminal investigators and administrative investigations.

Contrary to OTP assertions, convening some components of the larger national effort as purely administrative efforts is not necessarily dispositive. Many high-profile investigations around the world utilise formalised investigative structures that are designed to fold into

\footnotetext{
${ }^{120}$ Gaddafi and al-Senussi, Appeals Chamber Judgment on Admissibility (n 40) para 220.

${ }^{121}$ Dorota Marianna Banaszewska, 'Lex Specialis' in Frauke Lachenmann and Rüdiger Wolfrum (eds), The Law of Armed Conflict and the Use of Force: The Max Planck Encyclopedia of Public International Law (Oxford University Press 2017) 659, 660.

${ }^{122}$ Aurel Sari, 'Untangling Extra-territorial Jurisdiction from International Responsibility in Jaloud v. Netherlands: Old Problem, New Solutions?' (2014) 53 Military Law and the Law of War Review 287.
} 
subsequent prosecutorial processes. Prominent examples include, inter alia, the Joint Incident Assessment Teams used by the International Security Assistance Force (ISAF) in Afghanistan; ${ }^{123}$ modern American administrative inquiries such as the Taguba Report into the crimes committed at Abu Ghraib; ${ }^{124}$ the published report conducted by US Forces Afghanistan analysing the Kunduz bombing; ${ }^{125}$ and the famous Peers Commission of the Vietnam era. ${ }^{126}$ Other domestic systems rely upon UN fact-finding missions convened by the Human Rights Council as a predicate to later development and documentation supporting potential criminal charges. Of particular note, although the OTP request in Afghanistan discounted any US investigative efforts, it relied upon the US Forces Afghanistan administrative investigation ${ }^{127}$ to support the finding that criminal charges would be unwarranted for the accidental destruction of the Médecins Sans Frontières hospital in Kunduz. ${ }^{128}$ If the OTP can exercise its prosecutorial discretion following careful analysis of administrative efforts, why does it presume authority to deny domestic prosecutors that same professional latitude?

The role of prosecutors in relation to the investigative team provides another important measure of sufficiency under Article 17. Some investigations are organised as exclusively criminal inquiries with intrinsic relationships with supervising lawyers empowered to begin criminal proceedings. In other domestic systems, protected information collected by safety investigations may guide independent criminal investigators in developing case files and charging recommendations. Closed case files may also provide corroboration of facts developed in criminal inquiries. The gold standard in this context is to examine domestic investigations, regardless of their genesis or form, to identify good-faith independent prosecutorial assessments based on the available evidence.

In Israel, for example, operational investigations conducted to determine facts immediately following reports of impropriety are subsequently subject to independent assessment by the senior

${ }^{123}$ Center for Civilians in Conflict, 'Civilian Harm Tracking: Analysis of ISAF Efforts in Afghanistan' 19 May 2014, https://civiliansinconflict.org/publications/research/civilian-harm-tracking-analysis-isaf-efforts-afghanistan.

124 'Article 15-6 Investigation of the 800th Military Police Brigade', https://fas.org/irp/agency/dod/taguba.pdf.

${ }^{125}$ United States Forces-Afghanistan, 'Investigation Report of the Airstrike on the Médecins Sans Frontières/ Doctors Without Borders Trauma Center in Kunduz, Afghanistan on 3 October 2015', 21 November 2015, http://fpp.cc/wp-content/uploads/01.-AR-15-6-Inv-Rpt-Doctors-Without-Borders-3-Oct-15_CLEAR.pdf.

${ }^{126}$ Library of Congress, 'Report of the Department of the Army Review of the Preliminary Investigations into the My Lai Incident', https://www.loc.gov/rr/frd/Military_Law/Peers_inquiry.html.

${ }^{127}$ For the US Army Kunduz investigation see United States Forces-Afghanistan (n 125).

${ }^{128}$ Afghanistan, OTP Request (n 78) para 259 (references removed) ('In another incident on 3 October 2015, a US armed forces gunship air crew attacked the Kunduz Trauma Centre operated by Médecins Sans Frontières [(MSF)] during military operations in the city of Kunduz. At least 42 persons were reportedly killed with up to 30 persons injured, and the main hospital building was substantially destroyed. According to a US military investigation, "the personnel involved did not know that they were striking a medical facility", despite confirming that "MSF officials provided the correct grid coordinates for the MSF Trauma Center to several U.S. government officials and that the location was properly entered on the U.S. military's 'No Strike List' database". The investigation concluded that a "combination of factors caused both the Ground Force Commander and the air crew to believe mistakenly that the air crew was firing on the intended target, an insurgent-controlled site approximately 400 meters away from the MSF Trauma Center", citing "human errors, compounded by process and equipment failures" as well as "[f]atigue and high operational tempo". Although the information available indicates that MSF had taken a number of concrete measures to increase the visibility of the hospital and inform the parties of its location, including during the course of the incident, the Prosecution is unable at this stage to conclude that there is a reasonable basis to believe that the MSF medical facility was intentionally attacked'). 
military attorney charged with convening and coordinating criminal investigations. When paired with independent prosecutorial discretion, the administrative form of any investigation may well satisfy the intent of the Rome Statute. In assessing diverse processes in domestic systems, inadmissible investigations should demonstrate a high degree of coordination, independence and good-faith impartiality that operates free of bias arising from normal lines of operational authority. Results of a particular inquiry into a particular accused do not provide prima facie evidence that the system was designed to shield a particular perpetrator from accountability. ${ }^{129}$ The OTP should not be permitted to dismiss domestic efforts with no analysis or legal template.

Considerations of timing provide another important variable in weighing the genuine character of domestic efforts. Some domestic efforts focus more on efficiency and ensure rapid fact finding. This genre of investigation is prompt but self-contained. In some systems, such as the Service Inquiry provisions in the United Kingdom, ${ }^{130}$ evidence provided to investigators cannot be incorporated into parallel criminal investigations. These investigations have narrower, more defined purposes than the expansive scope typically found in UN inquiries. ${ }^{131}$ They are more akin to the safety investigations in US military practice or the Joint Incident Assessment Teams (referred to in the media as JIAT) commonly employed by NATO in Afghanistan. This category of processes seeks to provide detailed information regarding the facts and circumstances of each incident, but the overarching purpose is to rapidly capture lessons learned that might benefit future operations. Their very speed indicates good faith, particularly when paired with follow-on investigative or prosecutorial powers using other procedures. Effective investigations require on-scene lawyers to be astute and careful regarding the dissemination of information if there are simultaneous criminal or command investigations (designed to get to the facts and circumstances surrounding an accident) along with operational investigation (intended to find out the cause of the accident to prevent repetition of the same or similar accidents).

Pre-Trial Chambers to date have made none of the relevant inquiries; nor have they asked the OTP to provide its specific standards for dismissing domestic efforts. Admissibility analysis should document the form and function of domestic efforts in order to warrant inferences required under Article 17. This article concludes by advancing a series of recommendations that would serve the cause of justice while contributing to greater clarity over the appropriate extent of ICC prosecutorial discretion against sovereign states employing established domestic investigative procedures.

\section{Revitalising the Relationship between the Court and Domestic PROCESSES}

The Rome Statute nowhere specifies a regime for harmonising enforcement efforts between OTP investigative and prosecutorial efforts and those of domestic states. As a textual matter, the OTP

\footnotetext{
${ }^{129}$ Rome Statute (n 2) art 17(2)(a).

${ }^{130}$ Armed Forces (Service Inquiries) Regulations 2008 (UK Statutory Instruments 2008, No 1651), http://www. legislation.gov.uk/uksi/2008/1651/contents/made.

${ }^{131}$ UN Human Rights Council, 'Group of Eminent Experts on Yemen', updated 3 December 2020, https://www. ohchr.org/EN/HRBodies/HRC/YemenGEE/Pages/Index.aspx.
} 
must notify 'all States Parties and those States which, taking into account the information available, would normally exercise jurisdiction' prior to proceeding with a proprio motu investigation. $^{132}$ This obligation is subject to common sense limitation based on the needs of confidentiality and the preservation of evidence. Nor is it accompanied by any obligation to assist a state that is both willing and able to prosecute or investigate a perpetrator. ${ }^{133}$

This gap in the Rome Statute structure creates a one-sided scheme whereby states parties must comply with treaty-based obligations to cooperate at all stages of investigation and prosecution, ${ }^{134}$ but the Prosecutor need not reciprocate. The Statute creates an imbalance which, at best, undermines the rights of states to exercise complementarity. Current ICC jurisprudence creates barriers to the effective and efficient use of domestic forums that are capable of assisting the efforts of the Court to create a comprehensive system of criminal accountability. One immediate remedy for the current dystopian view of domestic jurisdiction would be for the Assembly of States Parties to amend Article 18 to create a symmetrical duty on the part of the OTP to notify any sovereign states that might have a valid basis to exercise jurisdiction over the offences of interest prior to the formal request to open an investigation.

\subsection{Amending Regulation 49}

No proponent of the Court should support the current practice by which the OTP can transition from $\mathrm{PE}$ into a formal investigation simply by ignoring extensive and costly domestic, and even multilateral, fact-finding and enforcement efforts. This illusion of inactivity is often artificial. Unsupported OTP assertions of domestic inactivity contravene the intent of the Rome Statute. Judges should amend Regulation $49^{135}$ to align pre-trial practice with the affirmative obligations expressed by Article 17. Adding a paragraph 1(c) to require analysis of admissibility would introduce clarity into the OTP assessments of domestic processes. It would also require tangible evidentiary evaluations by the OTP and prevent opportunities to ignore or bypass domestic efforts. This change, while textually minimal, would signal a profound shift in the current approach of the Court towards domestic states. Amending Regulation 49 would harmonise the free flow of communication between sovereign states and the Court at the PE phase and enhance efficiency throughout approved investigations.

\subsection{Utilising EXPERTS UNDER RegUlation 44}

Judges should begin to utilise Regulation 44, when necessary, as a check upon the unsupported assertions of the OTP. At the PE phase, judges have until now certified admissibility with no

\footnotetext{
${ }^{132}$ Rome Statute (n 2) art 18(1).

${ }^{133}$ See generally Michael A Newton, 'The Quest for Constructive Complementarity' in Stahn and El Zeidy (n 15) 304.

${ }^{134}$ Rome Statute (n 2) art 93.

${ }^{135}$ ICC, Regulations of the Court, ICC-BD/01-05-16, https://www.icc-cpi.int/Publications/Regulations-of-theCourt.pdf.
} 
understanding of the actions actually taken by domestic states, the intricacies of their systems, or the interrelationship of overlapping enforcement efforts. As such, there is no evidentiary basis for holding that the domestic state is 'unable or unwilling genuinely' to enforce criminal norms. Expert testimony under Regulation 44 would help to address this evidentiary void.

\subsection{Adding a Reciprocal Right in Article 15}

Article 15(3) of the Rome Statute provides that victims are permitted to make representations to the Pre-Trial Chamber upon presentation of a request by the OTP to open an investigation. The Assembly of States Parties should add a sentence to Article 15(3) that mirrors the sentiment of Article 18 by providing that '[a]ny state may challenge the prosecutor's determination that there is a reasonable basis to proceed with an investigation based on evidence that investigations or prosecutions would satisfy the criteria of Article 17'.

This amendment accords with the object and purpose of the Rome Statute on multiple levels. It would foster a climate of trust and cooperation between states and the Court. These amendments balance the operational aspects of a viable complementarity regime by providing for the sharing of information in both ICC and domestic investigations. It is also important to note that improving the constructive dynamic of a Court and domestic officials that seek the same goals of justice could also enhance the effectiveness of OTP investigations.

\subsection{Amending Articles 17 AND 112}

Finally, at the time of this writing, there is no established mechanism to ensure communication between sovereign states and the Court. The OTP remains free to make inaccurate representations regarding the scope and content of domestic investigations and/or enforcement. Court officials often rely on publicly available data or uncorroborated information provided by third parties. States should create a domestic focal point akin to the provision of a central authority to coordinate among governments in the context of transnational child abduction. ${ }^{136}$

In order to clarify the appropriate balance of adjudicative authority at all phases of ICC proceedings, Article 17(3) should incorporate a new sentence to the effect that the admissibility of domestic states cannot arise solely from domestic processes that demonstrate 'good faith differences in the application of law. The Prosecutor shall give deference to effective investigations and fact-finding efforts of sovereign states in relation to decisions related to the form and feasibility of charging decisions by states in proceedings against state nationals or others within domestic criminal jurisdiction'. When paired with the amendment to Regulation 44 noted above, this would generate concrete analysis of the systematic sufficiency of domestic efforts. The spirit of the Rome Statute demands a holistic analysis rather than a high-handed dismissal of domestic efforts by the OTP.

${ }^{136}$ See, generally, Hague Convention on the Civil Aspects of International Child Abduction (entered into force 1 December 1983) 1343 UNTS 89. 
A standing sub-committee of states parties under Article 112(4) could increase the efficiency and economy of the Court. Permanent channels for consistent assistance to the OTP would also benefit open discussion of complementarity-related issues. The Committee would provide a much-needed forum for the sharing of mechanisms used by other states to implement a positive and constructive relationship with the Court. The OTP would gain an identifiable point of assistance and support from states parties. Conversely, states parties would benefit from a focal point from which to evaluate the operational implementation of the concept of complementarity as well as the obstacles towards its implementation.

In Article 112, after paragraph (4), the following language should be added as a new paragraph (4)bis:

The Assembly shall have a standing Complementarity Coordination Committee composed of seven representatives selected by States Parties to serve as the forum for collective consultation with the Court and to develop consensus on admissibility and related matters. This Committee shall oversee the Court's admissibility review procedures under this Statute with a view to facilitating effective domestic investigations.

Serving as a focal point for Court officials to raise concerns in connection with admissibility challenges, the Committee could increase cooperative synergy between states parties and the organs of the Court. A forum for communication and consultation should strive to provide a unified voice as the contours of complementarity are developed. These amendments could align Article 17 with Article 20 by focusing on the underlying conduct rather than the precise formulation relied upon by national authorities. The net effect of these changes would foster a constructive and continuing dialogue, while enhancing effective investigations of alleged atrocities.

\section{Conclusions}

A position of latent hostility towards sovereign states that seek to implement their organic prosecutorial capacity forces Chambers to engage in distorted readings of the admissibility provisions of the Rome Statute. Admissibility is an important precept that applies to all sovereign states that are potentially subject to the exercise of ICC jurisdiction. In the words of the first ICC Prosecutor: ${ }^{137}$

The principle of complementarity represents the express will of States Parties to create an institution that is global in scope while recognising the primary responsibility of States themselves to exercise criminal jurisdiction. The principle is also based on considerations of efficiency and effectiveness since States will generally have the best access to evidence and witnesses.

Effacing the cornerstone principle of complementarity at any phase of ICC proceedings will erode political support for the Court over time. The transition from PE to authorised ICC

${ }^{137}$ ICC-OTP, Paper on Some Policy Issues Before the Office of the Prosecutor, September 2003, 4. 
investigations represents an untapped potential for synergy between the Court and competent domestic authorities. The ICC cannot sustain for long an adversarial posture in opposition to sovereign states that are working in good faith to investigate allegations and prosecute perpetrators when feasible. Admissibility should operate as a seamless systematic check on potential abuses of domestic duties. Its purpose is to fill enforcement gaps in the international community rather than discredit or displace functional domestic processes. Nor should experts in the field who desire an institutionalised system of accountability be content with the reality that the linkage between global and local justice has developed into a 'worrisome embrace'. ${ }^{138}$ Current developments align alarmingly with that prediction.

The jurisprudence and practice of the ICC should not evolve to the point that the sole discretion of the OTP displaces domestic investigative efforts or prosecutions. The tenets of the Rome Statute apply irrespective of the seniority of potential perpetrators, or their state of nationality. By extension, conformity with the Rome Statute demands that domestic investigation or adjudication is never presumed to be less desirable than disposition by the ICC. The Statute requires careful analysis and granular assessment of the motivations and sufficiency of sovereign investigatory efforts and charging decisions. Current practice transforms admissibility considerations at the PE phase into a hollow shadow of the substantive power envisioned during negotiations that led to the Rome Statute. The changes proposed above will help to address the ongoing alteration of the cornerstone concept of complementarity. States parties would be wise to address these disquieting signals and move swiftly to restore a climate of communication and cooperative synergy.

\footnotetext{
${ }^{138}$ Payam Akhavan, 'Complementarity Conundrums: The ICC Clock in Transitional Times' (2016) 14 Journal of International Criminal Justice 1043, 1045.
} 